\title{
A New Attempt of Using Crushed Plastic Solid Wastes in Water Filtration
}

\author{
Jabbar Hammood Abdulnabi Al-Baidhani and Mukhtar Dh. Shubir \\ Department of Civil Engineering, College of Engineering, Babylon University, Babylon 51002, Iraq
}

\begin{abstract}
The aim of this new study is to investigate the ability of using crushed plastic solid wastes in water filtration by using a pilot plant. Two sets of filters were used. The first set represents mono media filters. The first filter is a sand media with effective size of $0.65 \mathrm{~mm}$ and the others three are plastic media with different grain sizes. The second set represents dual media filters with different depths, the filters were made to operate with the same effective size $(0.6-1.0 \mathrm{~mm})$. These filters were subjected to the same operating conditions of filtration rates and influent turbidity. The filters were operated at rates of 5, 7.5, 10, and $12.5 \mathrm{~m} / \mathrm{h}$ in order to find the optimum filtration velocity with influent turbidity ranged between 7 and 10 NTU (nephelometric turbidity unit). The results indicated that the single plastic filters and the dual filters produced water of the same high quality as the sand filter. Plastic filters were slower in the development of head losses by about of 8\%-78\% less and they have longer running time than the sand filter, while the dual filters were slower in the development of head losses by about of $14 \%-16 \%$ and they have longer running time by about of $12 \%-40 \%$ than the sand filter.
\end{abstract}

Key words: Filtration, pilot plant, plastic media, dual media, turbidity.

\section{Introduction}

The best and most economical way to increase the capacity of the existing water treatment plants is to increase its rate of operation rather than to build additional units [1]. This may be achieved by improving the performance of the filters, such as changing the filter medium. The ideal filter medium should have such a size and material that will provide a satisfactory effluent, retain the maximum quantity of solids and is cleaned with a minimum volume of washing water [2]. It should be light in weight, enough to allow sufficient depth for long filter runs and graded to allow effective backwash cleaning [3]. Dual filters may be one of the alternatives for this situation.

Different materials are used in dual filters. Eunpu [4] showed that limonite is more efficient than garnet as a filter medium. Mixed media of coal and sand were

Corresponding author: Jabbar Hammood Abdulnabi Al-Baidhani, Dr., assistant professor, research field: civil and environmental engineering. E-mail: jabbar_albaidhani@yahoo.com. tested by Westerhoff [5]. This filter produced water of very low turbidity compared with sand filters.

Al-Rawi, Mohammed, Yohe and Getting [6-8] used anthracite. They achieved significant turbidity removal, long filter runs, less head losses with less washing water requirements in the tested filters. Al-Anbari and Al-Ansary [9, 10] showed that filters of single media (porcelanite and kaolinite) gave better results in turbidity removal and NWP (net water product) value ( $\mathrm{m}^{3} / \mathrm{run}$ ) than in sand filters. This was because of their higher porosity and angular grain surface textures.

Also, Al-Ansary [10] indicated that porcelanite filters had more length in filter runs and less head losses during filtration by nearly $40 \%$ than sand filters. Al-Najjar [11] used granular ninivite rock as the dual medium in the filters, where Al-Auraji [12] used burnt kaolinite and anthracite. They also reached the same conclusions that they are lower head losses, longer filtration runs, and better water quality.

It is worth noting that no attempt has been made in Iraq to use crushed plastic solid waste as a porous 
media in water filtration. Therefore, the main objective of this paper is the using of plastic media in water filtration in comparison with conventional medium to reduce plastic solid wastes and to improve water filtration efficiency.

\section{Materials and Methods}

A pilot plant constructed similarly to the conventional water treatment plant is employed for the purposes of this work. Fig. 1 illustrates the units of the used pilot plant. Table 1 explains the units and process variables. Filtration system consists of four PVC (polyvinylchloride) column filters, acting parallel and simultaneously, the diameter and height of each

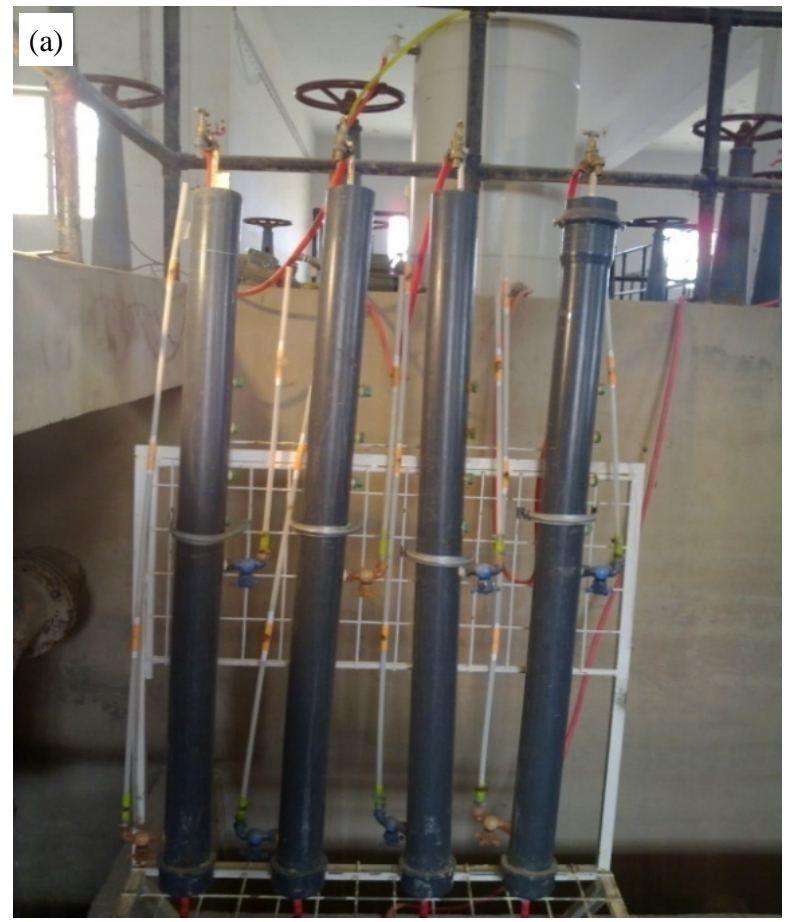

column filter was $8 \mathrm{~cm}$ and $150 \mathrm{~cm}$, respectively.

In the first stage, the first column was packed with $50 \mathrm{~cm}$ sand to act as a single-medium filter and the last three columns were packed with $50 \mathrm{~cm}$ of plastic with different particle size. In the second stage, the first column was packed with $50 \mathrm{~cm}$ sand and the last three columns contain plastic media over sand with different depth. Fig. 2 shows the details of filter unit.

The filter media used in this study is the plastic waste where most of these materials were PP (polypropylene) and PVC (polyvinylchloride). It is collected, cleaned, crushed (by mechanical instrument), and then sieved to obtain three types of grain sizes. Tables 2 and 3 explain the physical

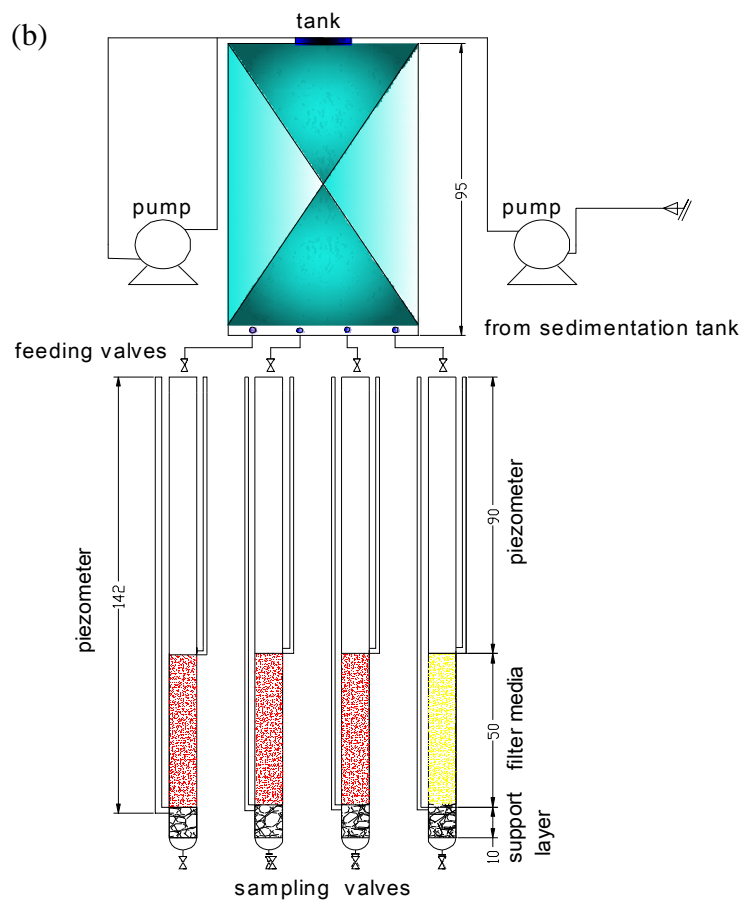

Fig. 1 The units of the used pilot plant: (a) a picture of the built filtration unit; (b) schematic diagram of the pilot plant.

Table 1 Process variables and conditions.

\begin{tabular}{|c|c|}
\hline Parameters & Remarks \\
\hline Turbid water & Effluent from sedimentation tank, having raw turbidity ranging from 7.0 to $10 \mathrm{NTU}$ \\
\hline $\begin{array}{l}\text { Temperature, TDS (total } \\
\text { dissolved solid), conductivity } \\
\text { and } \mathrm{pH}\end{array}$ & $15^{\circ} \mathrm{C}-18{ }^{\circ} \mathrm{C}, 600-750 \mathrm{mg} / \mathrm{L}, 1,200-1,500 \mu \mathrm{S} / \mathrm{cm}$, and 7.5-8.2 \\
\hline Filter media & $\begin{array}{l}\text { Two sets, the first consists of three plastic media filters and the } 4 \text { th of sand media filter, the second } \\
\text { consists of three dual media filters and the 4th of sand media filter, as shown in Fig. } 2\end{array}$ \\
\hline Treatment & Treatment conventional processes \\
\hline Filtration rate & $5,7.5,10$ and $12.5 \mathrm{~m} / \mathrm{h}$ \\
\hline Head loss & It is measured through water levels in tube connected at bottom end of filter \\
\hline
\end{tabular}



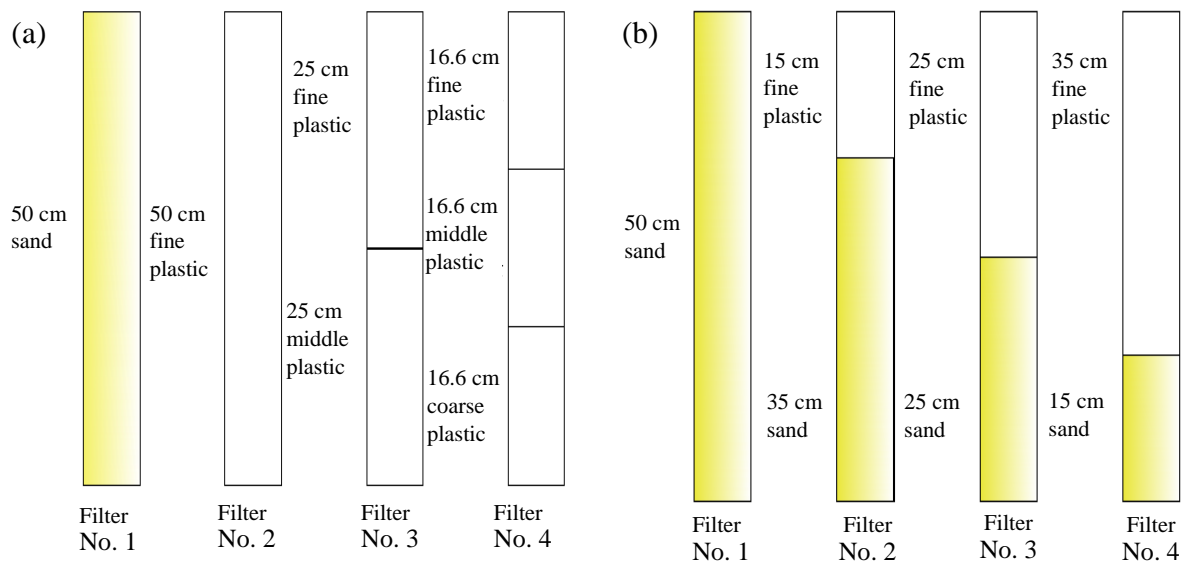

Fig. 2 Schematic diagram: (a) set No. 1; (b) set No. 2.

Table 2 Physical properties of the filter materials.

\begin{tabular}{lllll}
\hline Filter materials $(\mathrm{mm})$ & & Permeability $(\mathrm{cm} / \mathrm{s})$ & Specific gravity & Porosity (\%) \\
\hline Sand & $0.6-1.0$ & 0.324 & 2.570 & 40 \\
\hline \multirow{3}{*}{ Plastic } & $0.6-1.0$ & 0.648 & 0.974 & 53 \\
& $1.0-2.0$ & 0.851 & 0.974 & 61 \\
& $2.0-3.0$ & 0.908 & 0.974 & 64 \\
\hline
\end{tabular}

Table 3 Summary of experimental runs undertaken.

\begin{tabular}{|c|c|c|c|c|c|}
\hline Set No. & Filter No. & $\begin{array}{l}\text { Filter media } \\
\text { combinations }\end{array}$ & Layer depth (cm) & Grain size $(\mathrm{mm})$ & Purpose \\
\hline 1 & 1 & Sand & 50 & $0.6-1.0$ & Used as a control filter \\
\hline 1 & 2 & Plastic (one layer) & 50 & $0.6-1.0$ & $\begin{array}{l}\text { To show the ability of crushed plastic as } \\
\text { filtration media }\end{array}$ \\
\hline 1 & 3 & Plastic (two layers) & $25+25$ & $0.6-1.0$ and $1.0-2.0$ & $\begin{array}{l}\text { To show the effect of grain size on the removal } \\
\text { efficiency }\end{array}$ \\
\hline 1 & 4 & Plastic (three layers) & $16.6+16.6+16.6$ & $\begin{array}{l}0.6-1.0,1.0-2.0 \text { and } \\
2.0-3.0\end{array}$ & $\begin{array}{l}\text { To show the effect of grain size on the removal } \\
\text { efficiency and head loss }\end{array}$ \\
\hline 2 & 1 & Sand & 50 & $0.6-1.0$ & Used as a control filter \\
\hline 2 & 2 & Sand + Plastic & $35+15$ & $0.6-1.0$ & $\begin{array}{l}\text { To show the effect of plastic to sand ratio on } \\
\text { the running time and removal efficiency }\end{array}$ \\
\hline 2 & 3 & Sand + Plastic & $25+25$ & $0.6-1.0$ & $\begin{array}{l}\text { To show the effect of plastic to sand ratio on } \\
\text { the running time and removal efficiency }\end{array}$ \\
\hline 2 & 4 & Sand + Plastic & $15+35$ & $0.6-1.0$ & $\begin{array}{l}\text { To show the effect of plastic to sand ratio on } \\
\text { the running time and removal efficiency }\end{array}$ \\
\hline
\end{tabular}

properties of material used and summary of experimental runs, respectively and Fig. 3 shows the plastic media size. Sand media alone used as control filter and with dual media filter. A perforated stainless steel disc is used at the top of each column to prevent the plastic media from the volatilizations and at the bottom to support the filter media and to distribute the washing water.

A total of 32 runs for natural raw water turbidity are conducted. The filters are operated at rates of 5.0, 7.5, 10 , and $12.5 \mathrm{~m} / \mathrm{h}$, which is to 1.5 and 2.5 times the current prevailing filtration rate in the city water treatment plants. This practice may add to the economy of water treatment processes.

\section{Experimental Results}

\subsection{Set No. 1}

This set represents the mono media filters where fine plastic media in filter No. 2. Combined of fine and middle plastic media in filter No. 3 and filter No. 4 contains fine, middle and coarse plastic media which are compared with sand in filter No. 1. 

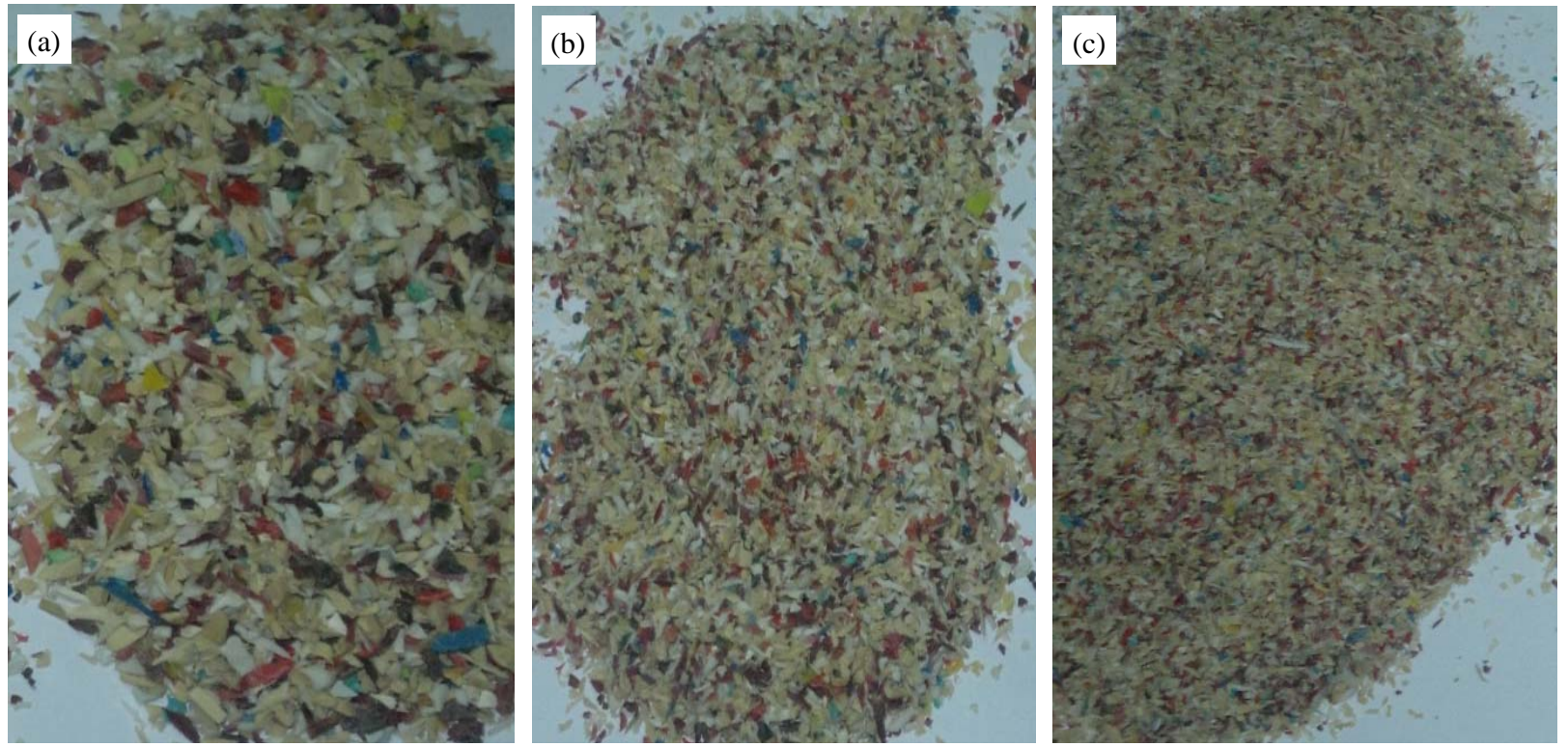

Fig. 3 Different sizes of plastic media filter: (a) 3-2 mm (coarse); (b) 2-1 mm (moderate); (c) 1-0.6 mm (fine).

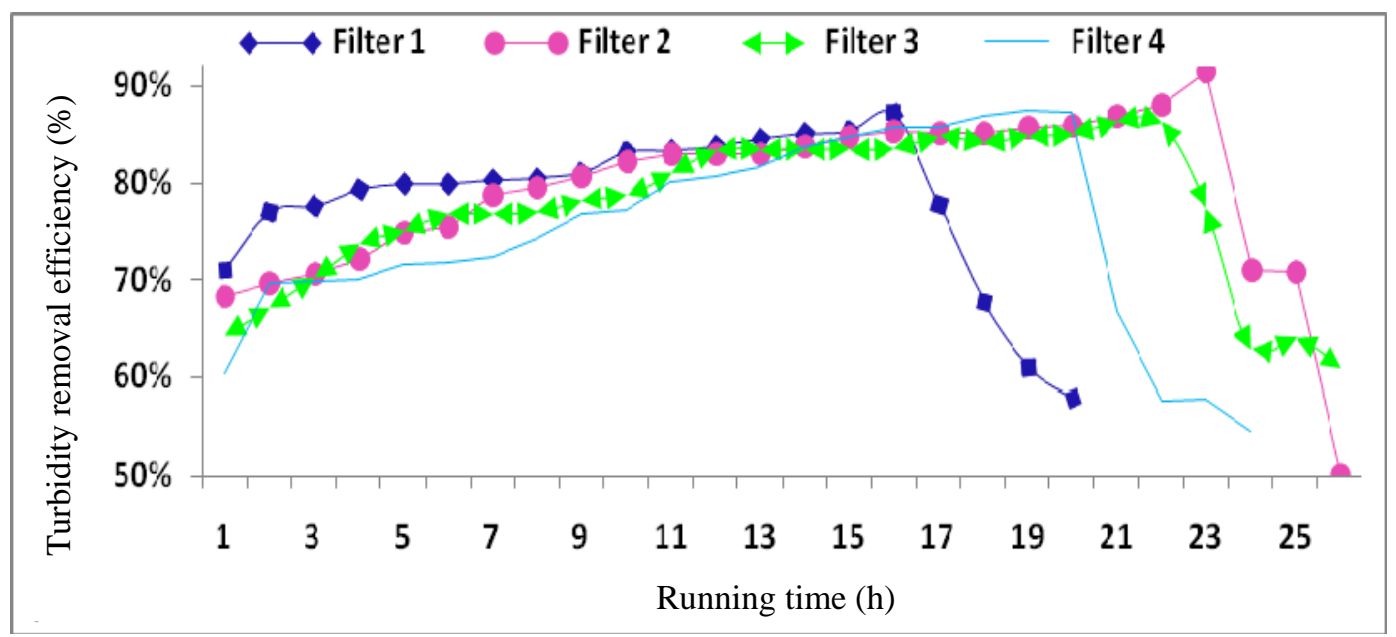

Fig. 4 Variation of turbidity removal efficiency with time of set No. 1 with filtration rate $5 \mathrm{~m} / \mathrm{h}$.

\subsubsection{The First Run}

The plastic media filters are of about 21\%-23\% slower in head loss development due to the sand media filter, and longer running time than sand filter by about $20 \%-30 \%$. The removal of TSS (total suspended solids) is low in the plastic filters. Fig. 4 shows the results of turbidity removal efficiency of the mono media filters with filtration rate of $5 \mathrm{~m} / \mathrm{h}$. Table 4 shows the experimental results of filtration rate of $5 \mathrm{~m} / \mathrm{h}$.

3.1.2 The Second Run

In this run, it was found that the filter No. 1 (sand filter) has higher turbidity removal than the filter No. 3 and No. 4, but it is very close to filter No. 2. Fig. 5 shows the results of turbidity removal efficiency of filtration rate of $7.5 \mathrm{~m} / \mathrm{h}$. It was found that the head loss of plastic media filters is less than of sand media filter by about of $62 \%-78 \%$. Also, it is important to indicate that the plastic filters have longer running time as compared with sand filter by a percentage of about 22\%. Table 5 shows the experimental results of filtration rate of $(7.5 \mathrm{~m} / \mathrm{h})$.

3.1.3 The Third Run

Fig. 6 shows the results of turbidity removal efficiency 
Table 4 Experimental results for set No.1, first run $(5 \mathrm{~m} / \mathrm{h})$.

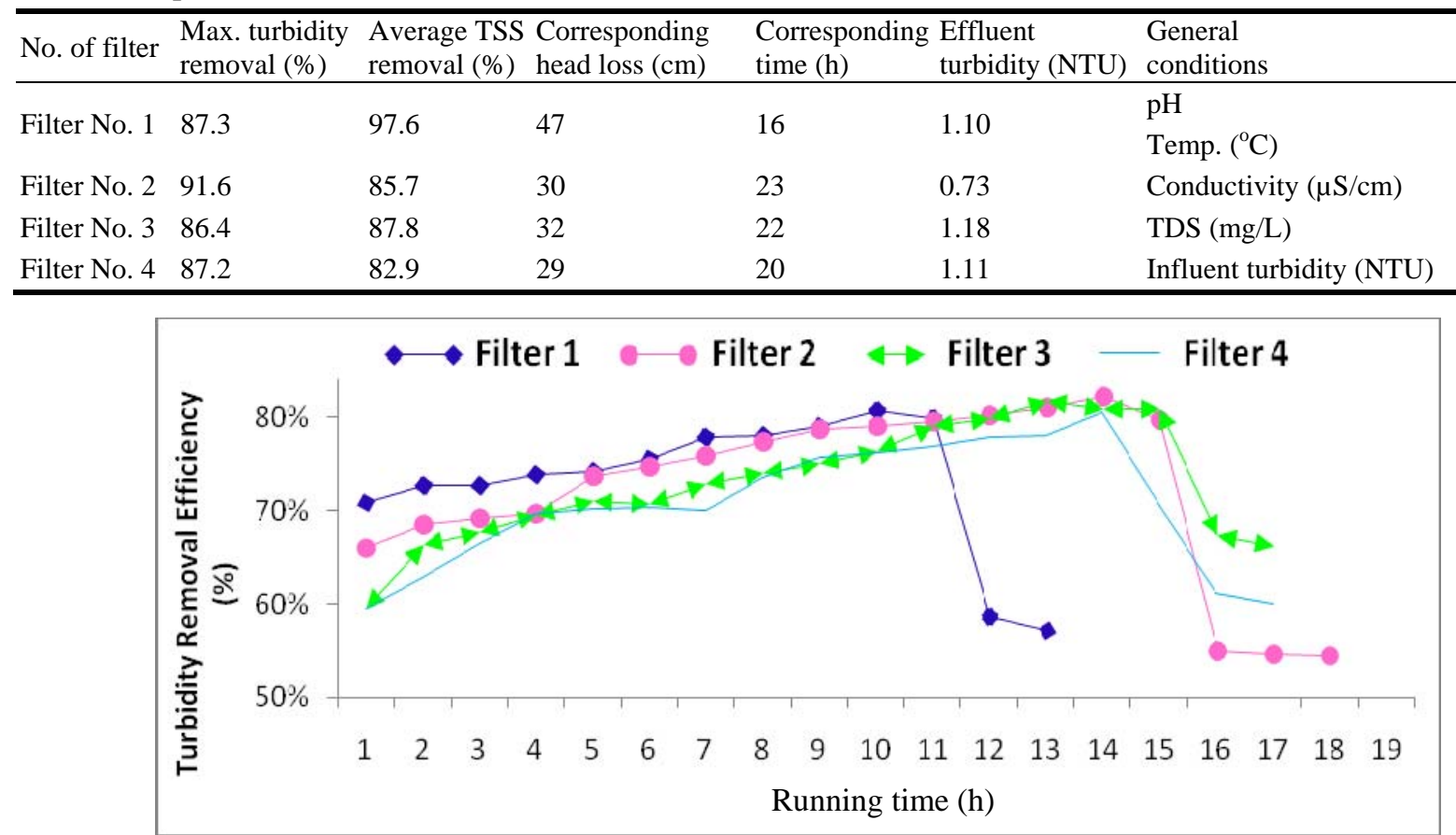

Fig. 5 Variation of turbidity removal efficiency with time of set No. 1 with filtration rate $7.5 \mathrm{~m} / \mathrm{h}$.

Table 5 Experimental results for set No.1, second run.

\begin{tabular}{|c|c|c|c|c|c|c|c|}
\hline $\begin{array}{l}\text { No. } \\
\text { of filter }\end{array}$ & $\begin{array}{l}\text { Max. turbidity } \\
\text { removal (\%) }\end{array}$ & $\begin{array}{l}\text { Average TSS } \\
\text { removal (\%) }\end{array}$ & $\begin{array}{l}\text { Corresponding head } \\
\text { loss }(\mathrm{cm})\end{array}$ & $\begin{array}{l}\text { Corresponding } \\
\text { time }(\mathrm{h})\end{array}$ & $\begin{array}{l}\text { Effluent turbidity } \\
\text { (NTU) }\end{array}$ & $\begin{array}{l}\text { General } \\
\text { conditions }\end{array}$ & Values \\
\hline \multirow{2}{*}{ Filter No. 1} & \multirow{2}{*}{80.8} & \multirow{2}{*}{92.6} & \multirow{2}{*}{70} & \multirow{2}{*}{11} & \multirow{2}{*}{1.84} & $\mathrm{pH}$ & 7.9 \\
\hline & & & & & & Temp. $\left({ }^{\circ} \mathrm{C}\right)$ & 15.1 \\
\hline Filter No. 2 & 82.4 & 85.4 & 26 & 14 & 1.69 & $\begin{array}{l}\text { Condictiviy } \\
(\mu \mathrm{S} / \mathrm{cm})\end{array}$ & 1,260 \\
\hline Filter No. 3 & 80.9 & 75.8 & 15 & 15 & 1.83 & TDS (mg/L) & 640 \\
\hline Filter No. 4 & 80.6 & 73.1 & 25 & 14 & 1.86 & $\begin{array}{l}\text { Influent } \\
\text { turbidity (NTU) }\end{array}$ & 9.57 \\
\hline
\end{tabular}

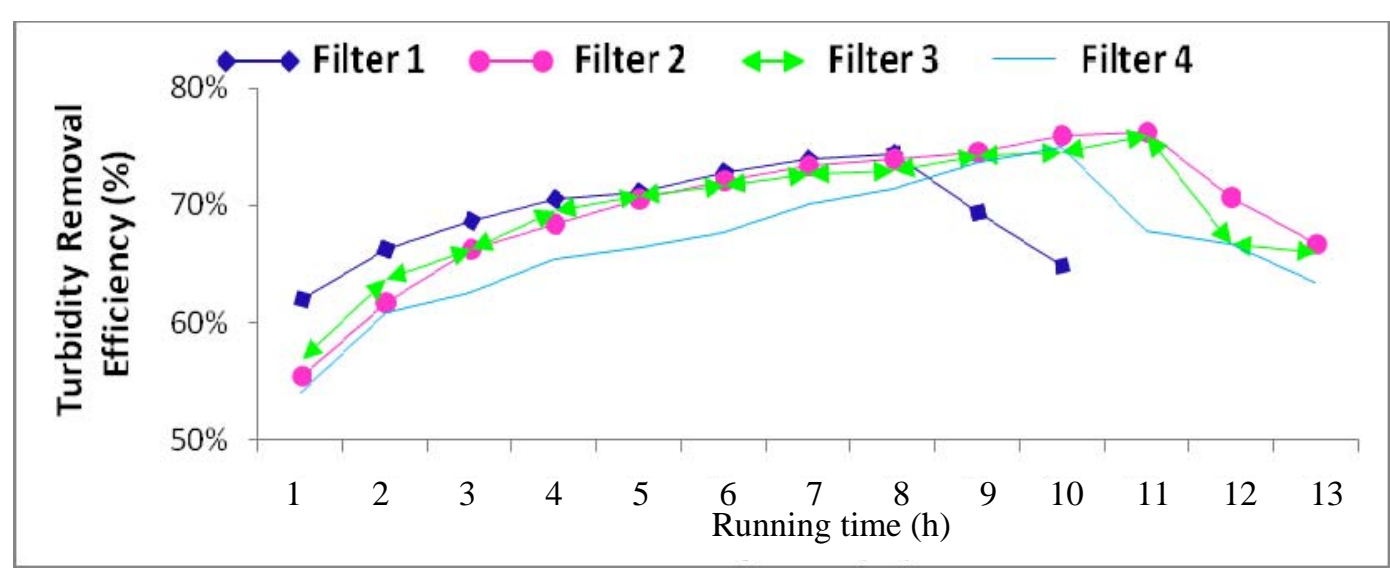

Fig. 6 Variation of turbidity removal efficiency with time of set No. 1 with filtration rate $10 \mathrm{~m} / \mathrm{h}$.

of mono media filters with filtration rate $10 \mathrm{~m} / \mathrm{h}$.

Where filter No. 1 (sand filter) has higher turbidity removal than filter No. 4 for the same time but it was close to filter No. 2 and filter No. 3.

The results indicate that the plastic media filters is about $8 \%-35 \%$ slower in head loss development due 
to the sand media filter and they are longer of running time than sand filter by about 25\%. The removal of TSS is low in the plastic filters by about 7\%-17\%. Table 6 shows the experimental results of filtration rate of $10 \mathrm{~m} / \mathrm{h}$.

\subsubsection{The Fourth Run}

In this run, it was found that the filter No. 1 (sand filter) has higher turbidity removal than filter No. 4 for the same time but it is almost equal to filter No. 2 and filter No. 3, the filter No. 2 and filter No. 3 have higher turbidity removal than filter No. 4. Fig. 7 shows the results of turbidity removal of filtration rate of $12.5 \mathrm{~m} / \mathrm{h}$. Also, it was noted that the plastic media filters is about 22\%-50\% slower in head loss development due to the sand media filter, and they have longer running time than sand filter by about
22\%. Table 7 shows the experimental results of filtration rate of $12.5 \mathrm{~m} / \mathrm{h}$.

\subsection{Set No. 2}

\subsubsection{The First Run}

The dual media filters are slower in head loss development due to the sand media filter, the dual filters are longer in running time than that of sand filter by about $12 \%$. Fig. 8 shows the results of turbidity removal of filtration rate of $5 \mathrm{~m} / \mathrm{h}$ for set No. 2. The removal efficiency of TSS is almost equal for all filters. The variation of sand to plastic ratio does not significantly affect the efficiency of filter No. 2, No. 3 and No. 4, but the large depth of plastic grains in filter No. 4 leads to increase running time. Table 8 shows the experimental results of filtration rate of 5

Table 6 Experimental results for set No. 1, third run.

\begin{tabular}{|c|c|c|c|c|c|c|c|}
\hline No. of filter & $\begin{array}{l}\text { Max. turbidity } \\
\text { removal (\%) }\end{array}$ & $\begin{array}{l}\text { Average TSS } \\
\text { removal (\%) }\end{array}$ & $\begin{array}{l}\text { Corresponding head } \\
\text { loss }(\mathrm{cm})\end{array}$ & $\begin{array}{l}\text { Corresponding } \\
\text { time }(\mathrm{h})\end{array}$ & $\begin{array}{l}\text { Effluent turbidity } \\
\text { (NTU) }\end{array}$ & $\begin{array}{l}\text { General } \\
\text { conditions }\end{array}$ & Values \\
\hline \multirow{2}{*}{ Filter No. 1} & \multirow{2}{*}{74.4} & \multirow{2}{*}{81.0} & \multirow{2}{*}{64} & \multirow{2}{*}{8} & \multirow{2}{*}{2.64} & $\mathrm{pH}$ & 7.9 \\
\hline & & & & & & Temp. $\left({ }^{\circ} \mathrm{C}\right)$ & 16 \\
\hline Filter No. 2 & 76.4 & 75.00 & 59 & 11 & 2.44 & $\begin{array}{l}\text { Condictivity } \\
(\mu \mathrm{S} / \mathrm{cm})\end{array}$ & 1,209 \\
\hline Filter No. 3 & 76.1 & 73.5 & 49 & 11 & 2.47 & TDS (mg/L) & 606 \\
\hline Filter No. 4 & 74.9 & 66.9 & 41 & 10 & 2.59 & Influent turbidity & 10.35 \\
\hline
\end{tabular}

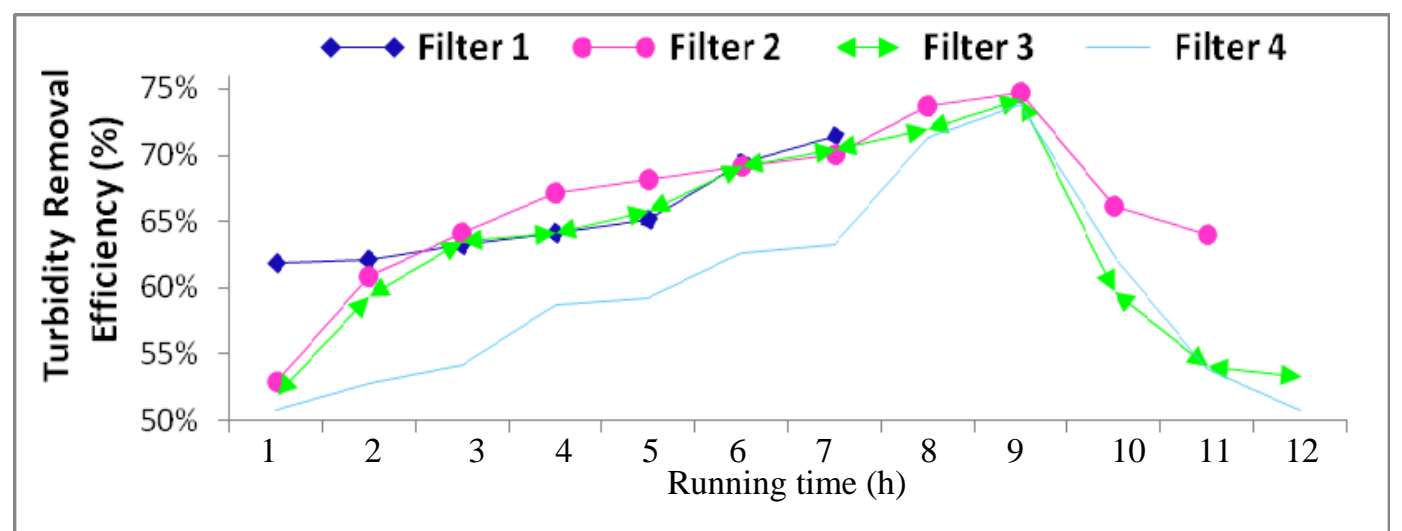

Fig. 7 Variation of turbidity removal efficiency with time of set No. 1 with filtration rate $12.5 \mathrm{~m} / \mathrm{h}$.

Table 7 Experimental results for set No. 1, fourth run.

\begin{tabular}{lllllllr}
\hline No. of filter $\begin{array}{l}\text { Max. turbidity } \\
\text { removal (\%) }\end{array}$ & $\begin{array}{l}\text { Average TSS } \\
\text { removal (\%) }\end{array}$ & $\begin{array}{l}\text { Corresponding } \\
\text { head loss }(\mathrm{cm})\end{array}$ & $\begin{array}{l}\text { Corresponding } \\
\text { time (h) }\end{array}$ & $\begin{array}{l}\text { Effluent turbidity } \\
(\mathrm{NTU})\end{array}$ & $\begin{array}{l}\text { General } \\
\text { conditions }\end{array}$ & Values \\
\hline Filter No. 1 & 71.4 & 75.2 & 90 & 7 & 2.15 & $\mathrm{pH}$ & 7.8 \\
& & & & & & Temp. $\left({ }^{\circ} \mathrm{C}\right)$ & 15.1 \\
Filter No. 2 & 74.8 & 62.7 & 70 & 9 & 1.90 & Condictivity $(\mu \mathrm{S} / \mathrm{cm})$ & 1,271 \\
Filter No. 3 & 74.2 & 61.3 & 45 & 9 & 1.94 & TDS (mg/L) & 635 \\
Filter No. 4 & 73.8 & 62.3 & 54 & 9 & 1.97 & Influent turbidity & 7.61 \\
\hline
\end{tabular}




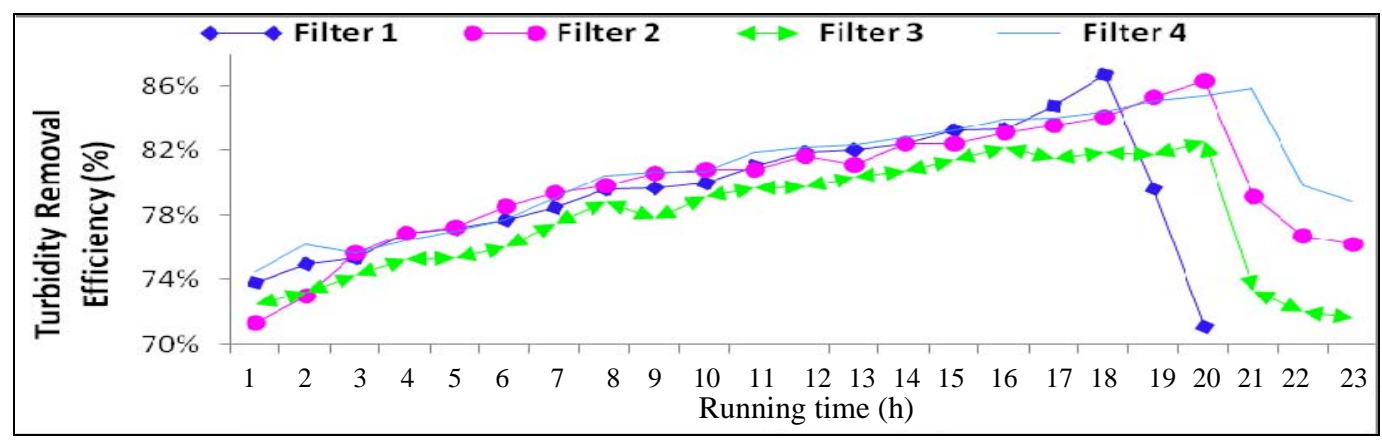

Fig. 8 Variation of turbidity removal efficiency with time of set No. 2 with filtration rate of $5 \mathrm{~m} / \mathrm{h}$.

Table 8 Experimental results for Set No. 2, first run.

\begin{tabular}{|c|c|c|c|c|c|c|c|}
\hline $\begin{array}{l}\text { No. of } \\
\text { filter }\end{array}$ & $\begin{array}{l}\text { Max. turbidity } \\
\text { removal (\%) }\end{array}$ & $\begin{array}{l}\text { Average TSS } \\
\text { removal (\%) }\end{array}$ & $\begin{array}{l}\text { Corresponding } \\
\text { head loss }(\mathrm{cm})\end{array}$ & $\begin{array}{l}\text { Corresponding } \\
\text { time }(\mathrm{h})\end{array}$ & $\begin{array}{l}\text { Effluent turbidity } \\
\text { (NTU) }\end{array}$ & $\begin{array}{l}\begin{array}{l}\text { General } \\
\text { conditions }\end{array} \\
\end{array}$ & Values \\
\hline \multirow{2}{*}{\multicolumn{2}{|c|}{ Filter No. 186.7}} & \multirow{2}{*}{88.0} & \multirow{2}{*}{64} & \multirow{2}{*}{18} & \multirow{2}{*}{1.08} & $\mathrm{pH}$ & 8.1 \\
\hline & & & & & & Temp. $\left({ }^{\circ} \mathrm{C}\right)$ & 19.8 \\
\hline \multicolumn{2}{|c|}{ Filter No. 286.3} & 86.5 & 59 & 20 & 1.11 & Condictivity $(\mu \mathrm{S} / \mathrm{cm})$ & 1,336 \\
\hline \multicolumn{2}{|c|}{ Filter No. 382.7} & 87.9 & 57 & 20 & 1.41 & TDS (mg/L) & 680 \\
\hline \multicolumn{2}{|c|}{ Filter No. 485.9} & 85.0 & 63 & 21 & 1.15 & Influent turbidity & 8.21 \\
\hline
\end{tabular}

$\mathrm{m} / \mathrm{h}$ for set No. 2.

\subsubsection{The Second Run}

The dual media filters are slower in head loss development due to the sand media filter, and they have longer running time than sand filter about 25\%. Fig. 9 shows the results of turbidity removal of filtration rate of $7.5 \mathrm{~m} / \mathrm{h}$ for set No. 2. The removal efficiency of TSS is approximately equal for all filters. The variation of sand to plastic ratio affects the efficiency in the dual filters where increasing of sand depth is more effective of turbidity removal and they have almost the same running time. Table 9 shows the experimental results of filtration rate of $7.5 \mathrm{~m} / \mathrm{h}$ for set No. 2.

Table 9 Experimental results for set No. 2, second run.

\begin{tabular}{|c|c|c|c|c|c|c|c|}
\hline No. of filter & $\begin{array}{l}\text { Max. turbidity } \\
\text { removal (\%) }\end{array}$ & $\begin{array}{l}\text { Average TSS } \\
\text { removal (\%) }\end{array}$ & $\begin{array}{l}\text { Corresponding } \\
\text { head loss }(\mathrm{cm})\end{array}$ & $\begin{array}{l}\text { Corresponding } \\
\text { time (h) }\end{array}$ & $\begin{array}{l}\text { Effluent turbidity } \\
\text { (NTU) }\end{array}$ & $\begin{array}{l}\text { General } \\
\text { conditions }\end{array}$ & Values \\
\hline \multirow{2}{*}{ Filter No. 1} & \multirow{2}{*}{81.0} & \multirow{2}{*}{80.0} & \multirow{2}{*}{71} & \multirow{2}{*}{11} & \multirow{2}{*}{1.47} & $\mathrm{pH}$ & 8.2 \\
\hline & & & & & & Temp. $\left({ }^{\circ} \mathrm{C}\right)$ & 19.7 \\
\hline Filter No. 2 & 81.4 & 80.8 & 71 & 15 & 1.44 & $\begin{array}{l}\text { Condictivity } \\
(\mu \mathrm{S} / \mathrm{cm})\end{array}$ & 1,524 \\
\hline Filter No. 3 & 80.5 & 86.8 & 51 & 14 & 1.51 & TDS (mg/L) & 762 \\
\hline Filter No. 4 & 82.2 & 81.4 & 69 & 15 & 1.38 & $\begin{array}{l}\text { Influent turbidity } \\
\text { (NTU) }\end{array}$ & 7.81 \\
\hline
\end{tabular}

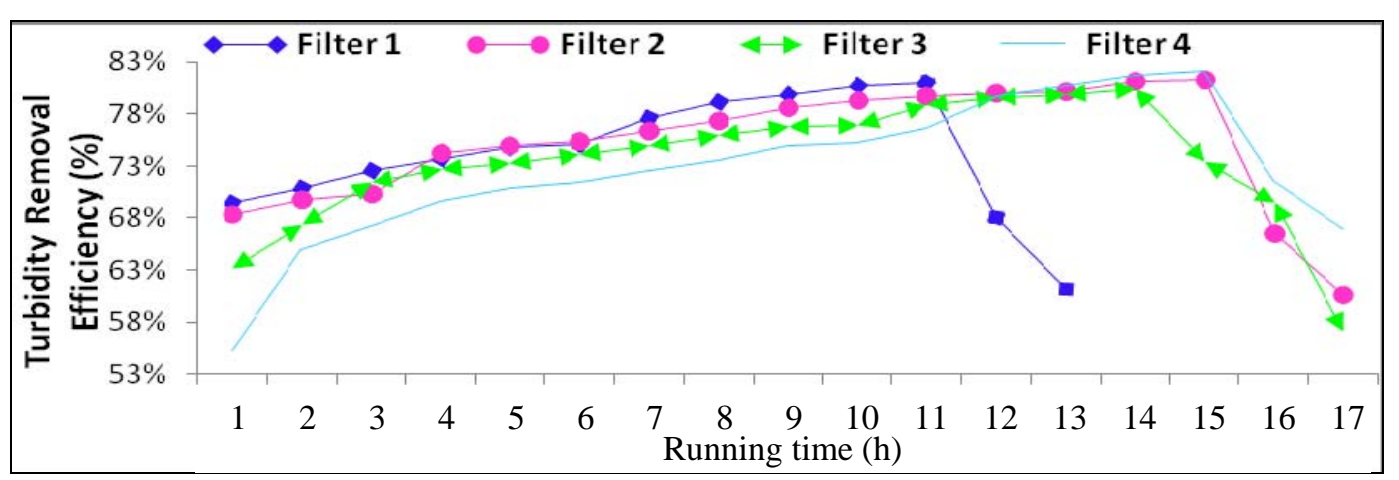

Fig. 9 Variation of turbidity removal efficiency with time of set No. 2 with filtration rate $7.5 \mathrm{~m} / \mathrm{h}$. 


\subsubsection{The Third Run}

The dual media filters are slower in head loss development due to the sand media filter and longer running time than that of sand filter by about 27\%-33\%. Fig. 10 shows the results of turbidity removal of filtration rate of $10 \mathrm{~m} / \mathrm{h}$ for set No. 2. The removal efficiency of TSS is approximately equal for all filters. The variation of sand to plastic ratio affects the efficiency in the dual filters where the turbidity removal efficiency increases when sand depth increased, and they almost have the same running time. Table 10 shows the experimental results of filtration rate of $10 \mathrm{~m} / \mathrm{h}$ for set No. 2 .

\subsubsection{The Fourth Run}

It was found that the dual media filters are slower in head loss development due to the sand media filter and they are of longer running time than sand filter by about 25\%-40\%. Fig. 11 shows the results of turbidity removal of filtration rate of $12.5 \mathrm{~m} / \mathrm{h}$ for set No. 2 . The removal efficiency of TSS was higher in filter No. 2 than filters No. 3 and No. 4. The variation of sand to plastic ratio affects the removal efficiency in the dual filters where the turbidity removal efficiency increased with increasing of sand depth and they are less running time. Table 11 shows the experimental results of filtration rate of $12.5 \mathrm{~m} / \mathrm{h}$ for set No. 2 .

\section{Effect of Filtration Velocity}

Four different velocities are tested for all types of media combinations in this study. The performance of

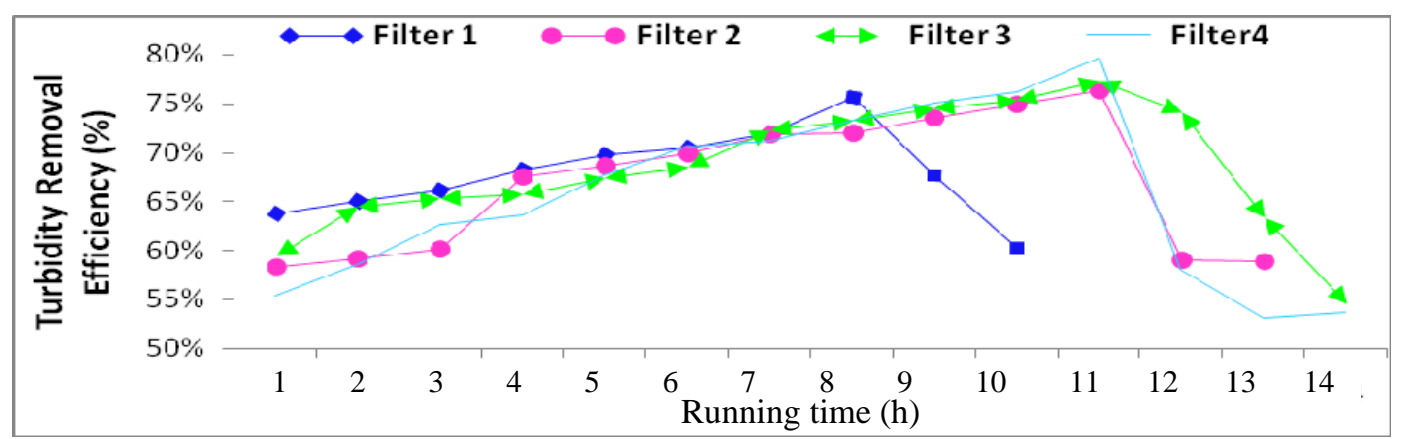

Fig. 10 Variation of turbidity removal efficiency with time of set No. 2 with filtration rate $10 \mathrm{~m} / \mathrm{h}$.

Table 10 Experimental results of set No. 2, third run.

\begin{tabular}{|c|c|c|c|c|c|c|c|}
\hline No. of filter & $\begin{array}{l}\text { Max. turbidity } \\
\text { removal (\%) }\end{array}$ & $\begin{array}{l}\text { Average TSS } \\
\text { removal (\%) }\end{array}$ & $\begin{array}{l}\text { Corresponding } \\
\text { head loss }(\mathrm{cm}) \\
\end{array}$ & $\begin{array}{l}\text { Corresponding } \\
\text { time (h) }\end{array}$ & $\begin{array}{l}\begin{array}{l}\text { Effluent turbidity } \\
\text { (NTU) }\end{array} \\
\end{array}$ & $\begin{array}{l}\text { General } \\
\text { conditions }\end{array}$ & Values \\
\hline \multirow{2}{*}{ Filter No. 1} & \multirow{2}{*}{75.7} & \multirow{2}{*}{82.1} & \multirow{2}{*}{64} & \multirow{2}{*}{8} & \multirow{2}{*}{1.93} & $\mathrm{pH}$ & 8.0 \\
\hline & & & & & & Temp. $\left({ }^{\circ} \mathrm{C}\right)$ & 20 \\
\hline Filter No. 2 & 76.4 & 80.8 & 67 & 11 & 1.87 & $\begin{array}{l}\text { Condictivity } \\
(\mu \mathrm{S} / \mathrm{cm})\end{array}$ & 1,518 \\
\hline Filter No. 3 & 77.3 & 77.6 & 58 & 12 & 1.80 & TDS (mg/L) & 759 \\
\hline Filter No. 4 & 79.7 & 81.4 & 60 & 11 & 1.61 & $\begin{array}{l}\text { Influent turbidity } \\
\text { (NTU) }\end{array}$ & 7.94 \\
\hline
\end{tabular}

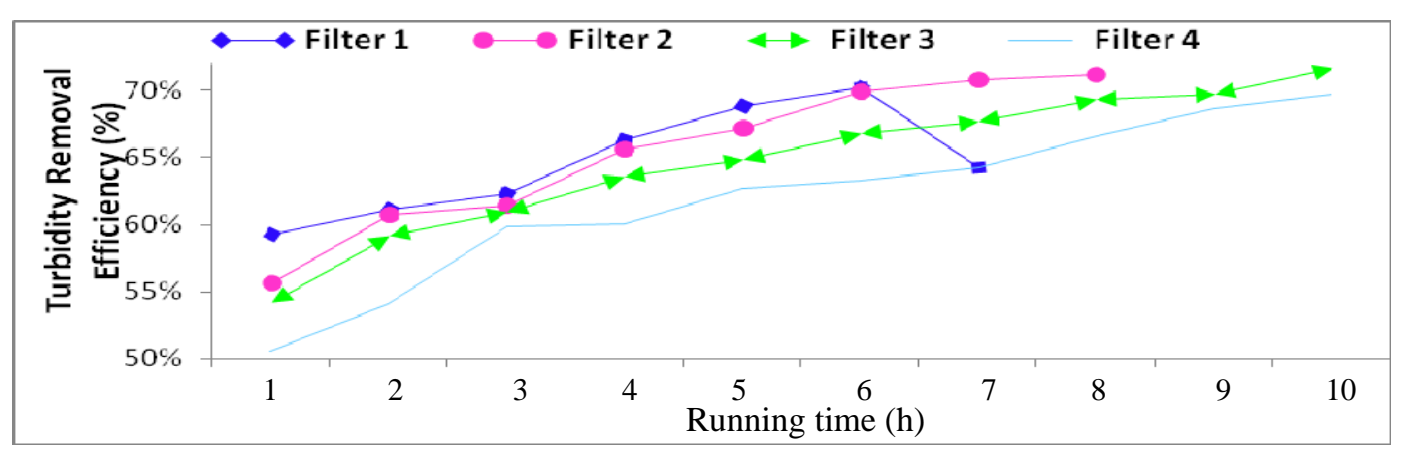

Fig. 11 Variation of turbidity removal efficiency with time of set No. 2 with filtration rate $12.5 \mathrm{~m} / \mathrm{h}$. 
filters with different velocities is shown in Tables 12 and 13. At the filtration velocity of $12.5 \mathrm{~m} / \mathrm{h}$, the water production rate is higher than all other filtration velocities in plastic media filters, while the filtration velocity of $10 \mathrm{~m} / \mathrm{h}$ gives higher water production in the dual media filters. In sand filters, the filtration velocities of $5,7.5$ and $10 \mathrm{~m} / \mathrm{h}$ are almost close to each other in water production.

Table 11 Experimental results for set No. 2, fourth run.

\begin{tabular}{|c|c|c|c|c|c|c|c|}
\hline No. of filter & $\begin{array}{l}\text { Max. turbidity } \\
\text { removal (\%) }\end{array}$ & $\begin{array}{l}\text { Average TSS } \\
\text { removal (\%) }\end{array}$ & $\begin{array}{l}\text { Corresponding } \\
\text { head loss }(\mathrm{cm})\end{array}$ & $\begin{array}{l}\text { Corresponding } \\
\text { time }(\mathrm{h})\end{array}$ & $\begin{array}{l}\text { Effluent turbidity } \\
\text { (NTU) }\end{array}$ & $\begin{array}{l}\begin{array}{l}\text { General } \\
\text { conditions }\end{array} \\
\end{array}$ & Values \\
\hline Filter No. 1 & 70.2 & 72.3 & 79 & 6 & 2.18 & $\begin{array}{l}\mathrm{pH} \\
\text { Temp. }\left({ }^{\circ} \mathrm{C}\right)\end{array}$ & $\begin{array}{r}7.8 \\
18.1\end{array}$ \\
\hline Filter No. 2 & 71.2 & 79.1 & 85 & 8 & 2.11 & Condictivity $(\mu \mathrm{S} / \mathrm{cm})$ & 1,348 \\
\hline Filter No. 3 & 71.7 & 72.7 & 83 & 10 & 2.07 & TDS (mg/L) & 675 \\
\hline Filter No. 4 & 69.7 & 69.5 & 72 & 10 & 2.22 & $\begin{array}{l}\text { Influent turbidity } \\
\text { (NTU) }\end{array}$ & 7.36 \\
\hline
\end{tabular}

Table 12 Filter performance of different filtration velocities of set No. 1.

\begin{tabular}{|c|c|c|c|c|c|c|}
\hline $\begin{array}{l}\text { Run } \\
\text { number }\end{array}$ & $\begin{array}{l}\text { Media combination } \\
(\mathrm{mm})\end{array}$ & $\begin{array}{l}\text { Filtration velocity } \\
(\mathrm{m} / \mathrm{h})\end{array}$ & $\begin{array}{l}\text { Max. head loss } \\
\text { development }(\mathrm{cm})\end{array}$ & $\begin{array}{l}\text { Average turbidity } \\
\text { removal (\%) }\end{array}$ & $\begin{array}{l}\text { Water production } \\
\left(\mathrm{m}^{3} / \text { run }\right)\end{array}$ & $\begin{array}{l}\text { Filter run } \\
\text { duration (h) }\end{array}$ \\
\hline \multirow{4}{*}{$\begin{array}{l}\text { Set No.1, } \\
\text { filter } \\
\text { No. } 1\end{array}$} & \multirow{4}{*}{$\begin{array}{l}\text { Sand } \\
(0.6-1.0)\end{array}$} & 5.0 & 85 & 78.2 & 0.503 & 20 \\
\hline & & 7.5 & 90 & 73.3 & 0.49 & 13 \\
\hline & & 10 & 88 & 69.5 & 0.502 & 10 \\
\hline & & 12.5 & 90 & 65.3 & 0.44 & 7 \\
\hline \multirow{4}{*}{$\begin{array}{l}\text { Set No.1, } \\
\text { filter } \\
\text { No. } 2\end{array}$} & \multirow{4}{*}{$\begin{array}{l}\text { Plastic } \\
(0.6-1.0)\end{array}$} & 5.0 & 52 & 79.1 & 0.653 & 26 \\
\hline & & 7.5 & 38 & 72.3 & 0.679 & 18 \\
\hline & & 10 & 72 & 69.7 & 0.653 & 13 \\
\hline & & 12.5 & 85 & 66.5 & 0.691 & 11 \\
\hline \multirow{4}{*}{$\begin{array}{l}\text { Set No.1, } \\
\text { filter } \\
\text { No. } 3\end{array}$} & \multirow{4}{*}{$\begin{array}{l}\text { Plastic } 50 \%[(0.6-1.0) \\
+(1.0-2.0)]\end{array}$} & 5.0 & 50 & 77.5 & 0.653 & 26 \\
\hline & & 7.5 & 31 & 72.5 & 0.679 & 18 \\
\hline & & 10 & 66 & 69.4 & 0.653 & 13 \\
\hline & & 12.5 & 76 & 63.2 & 0.754 & 12 \\
\hline \multirow{4}{*}{$\begin{array}{l}\text { Set No.1, } \\
\text { filter } \\
\text { No. } 4\end{array}$} & \multirow{4}{*}{$\begin{array}{l}\text { Plastic 33\% [(0.6-1.0) } \\
+(1.0-2.0)+(2.0-3.0)]\end{array}$} & 5.0 & 52 & 74.7 & 0.603 & 24 \\
\hline & & 7.5 & 40 & 70.6 & 0.641 & 17 \\
\hline & & 10 & 60 & 66.5 & 0.653 & 13 \\
\hline & & 12.5 & 79 & 59.5 & 0.754 & 12 \\
\hline
\end{tabular}

Table 13 Filter performance of different filtration velocities of set No. 2.

\begin{tabular}{|c|c|c|c|c|c|c|}
\hline $\begin{array}{l}\text { Run } \\
\text { number }\end{array}$ & $\begin{array}{l}\text { Media } \\
\text { combination }\end{array}$ & $\begin{array}{l}\text { Filtration velocity } \\
(\mathrm{m} / \mathrm{h})\end{array}$ & $\begin{array}{l}\text { Max. head loss } \\
\text { development }(\mathrm{cm})\end{array}$ & $\begin{array}{l}\text { Average turbidity } \\
\text { removal (\%) }\end{array}$ & $\begin{array}{l}\text { Water production } \\
\left(\mathrm{m}^{3} / \mathrm{run}\right)\end{array}$ & $\begin{array}{l}\text { Filter run } \\
\text { duration }(\mathrm{h})\end{array}$ \\
\hline \multirow{4}{*}{$\begin{array}{l}\text { Set No. 2, } \\
\text { filter } \\
\text { No. } 1\end{array}$} & \multirow{4}{*}{$\begin{array}{l}\text { Sand } \\
(0.6-1.0) \mathrm{mm}\end{array}$} & 5.0 & 85 & 79.533 & 0.503 & 20 \\
\hline & & 7.5 & 90 & 73.523 & 0.528 & 14 \\
\hline & & 10 & 83 & 67.970 & 0.503 & 10 \\
\hline & & 12.5 & 90 & 64.618 & 0.44 & 7 \\
\hline \multirow{4}{*}{$\begin{array}{l}\text { Set No. 2, } \\
\text { filter } \\
\text { No. } 2\end{array}$} & \multirow{4}{*}{$\begin{array}{l}75 \% \text { sand }(0.6-1.0) \mathrm{mm} \\
+25 \% \text { plastic }(0.6-1.0) \\
\mathrm{mm}\end{array}$} & 5.0 & 73 & 79.877 & 0.578 & 23 \\
\hline & & 7.5 & 85 & 75.038 & 0.641 & 17 \\
\hline & & 10 & 84 & 67.029 & 0.653 & 13 \\
\hline & & 12.5 & 85 & 65.332 & 0.471 & 7.5 \\
\hline \multirow{4}{*}{$\begin{array}{l}\text { Set No. 2, } \\
\text { filter } \\
\text { No. } 3\end{array}$} & \multirow{4}{*}{$\begin{array}{l}50 \% \text { sand }(0.6-1.0) \mathrm{mm} \\
+50 \% \text { plastic } 25 \% \\
\text { plastic }(0.6-1.0) \mathrm{mm}\end{array}$} & 5.0 & 71 & 77.819 & 0.578 & 23 \\
\hline & & 7.5 & 77 & 73.345 & 0.641 & 17 \\
\hline & & 10 & 73 & 68.328 & 0.704 & 14 \\
\hline & & 12.5 & 83 & 64.831 & 0.628 & 10 \\
\hline \multirow{4}{*}{$\begin{array}{l}\text { Set No. 2, } \\
\text { filter } \\
\text { No. } 4\end{array}$} & \multirow{4}{*}{$\begin{array}{l}25 \% \text { sand }(0.6-1.0) \mathrm{mm} \\
+75 \% \text { plastic }(0.6-1.0) \\
\mathrm{mm}\end{array}$} & 5.0 & 73 & 80.802 & 0.578 & 23 \\
\hline & & 7.5 & 82 & 72.680 & 0.641 & 17 \\
\hline & & 10 & 82 & 65.642 & 0.704 & 14 \\
\hline & & 12.5 & 72 & 61.936 & 0.628 & 10 \\
\hline
\end{tabular}


At filtration velocity of $5 \mathrm{~m} / \mathrm{h}$, the filter run time is higher than all other filtration velocities for all media combinations. In sand filter, the filter run time and water production rate are very low with filtration velocity of $12.5 \mathrm{~m} / \mathrm{h}$. The filtration velocity of $7.5 \mathrm{~m} / \mathrm{h}$ gives a fairly good result in terms of filter run time, water production and head loss development for all types of media combinations.

\section{Statistical Analysis}

\subsection{Developing Multiple Regression Model of Set No. 1}

Multiple linear regression models were developed by using (SPSS - statistical package for the social sciences, version 16) program to simulate the experimental results of plastic media filters. The independent and dependent variables were selected as shown in Table 14.

The model No. 1 was shown in Table 15, it is the most suitable model to express the efficiency of removal turbidity data due to the high coefficient of determination $\left(R^{2}\right)$ value of 0.912 and lower standard error.

Therefore, turbidity removal efficiency can be given by the following equation:

$$
\dot{\eta}=a \times X_{1}+b \times X_{2}+c \times X_{3}+d \times X_{4}+e
$$

Eq. (1) can be also written in terms of design parameters as shown in the equation below:

$$
\begin{aligned}
& \dot{\eta}=-43.169 \times d-0.012 \times h l-0.003 \times n_{1}-0.02 \times q \\
&+ 102.577
\end{aligned}
$$

\subsection{Developing Multiple Regression Model of Set No. 2}

Multiple linear regression models were developed by using (SPSS, version 16) program to simulate the experimental results of dual media filters. The independent and dependent variables were selected as shown in Table 16. Two models were examined by using this program. These models are shown in Table 17. The model No. 1 in Table 17 was found to be the most suitable model to express the efficiency of removal turbidity data due to the high coefficient of
Table 14 Dependent and independent variables of set No. 1.

\begin{tabular}{|c|c|c|c|}
\hline No. & Model & $\overline{R^{2}}$ & Standard error \\
\hline 1 & $\begin{array}{l}a X_{1}+b X_{2}+c X_{3}+d X_{4} \\
+e\end{array}$ & 0.912 & 2.696 \\
\hline 2 & $a X_{1}+b X_{2}+c X_{3}+d X_{4}$ & 0.994 & 8.730 \\
\hline
\end{tabular}

\begin{tabular}{lll}
\hline Description & Variable & Type \\
\hline \multirow{3}{*}{ Independent } & $X_{1}$ & Grain size $(d)(\mathrm{cm})$ \\
\cline { 2 - 3 } & $X_{2}$ & Head loss $(h l)(\mathrm{cm})$ \\
\cline { 2 - 3 } & $X_{3}$ & Fine layer ratio $\left(n_{l}\right)(\%)$ \\
& $X_{4}$ & Filtration rate $(q)(\mathrm{cm} / \mathrm{hr})$ \\
\hline Dependent & $Y$ & Turbidity removal efficiency $(\dot{\eta})$ \\
\hline
\end{tabular}

Table 15 Models tested by regression analysis of set No. 1.

Table 16 Dependent and independent variables of set No. 2.

\begin{tabular}{lll}
\hline Description & Variable & Type \\
\hline \multirow{3}{*}{ Independent } & $X_{1}$ & Plastic ratio $\left(n_{2}\right)(\%)$ \\
& $X_{2}$ & Headloss $(h l)(\mathrm{cm})$ \\
& $X_{3}$ & Permeability $(p)(\mathrm{cm} / \mathrm{hr})$ \\
& $X_{4}$ & Filtration rate $(q)(\mathrm{cm} / \mathrm{hr})$ \\
\hline Dependent & $Y$ & Turbidity removal efficiency $(\dot{\eta})$ \\
\hline
\end{tabular}

Table 17 Models tested by regression analysis of set No. 2 .

\begin{tabular}{llll}
\hline No. & Model & $R^{2}$ & Standard error \\
\hline 1 & $a X_{1}+b X_{2}+c X_{3}+d X_{4}+$ & 0.981 & 0.9178 \\
& $e$ & $a X_{1}+b X_{2}+c X_{3}+d X_{4}+$ & 0.995 \\
2 & $e$ & 7.977 \\
\hline
\end{tabular}

determination $\left(R^{2}\right)$ value of 0.981 and lower standard error.

Therefore, turbidity removal efficiency can be given by the following equation:

$$
\dot{\eta}=a \times X_{1}+b \times X_{2}+c \times X_{3}+d \times X_{4}+e
$$

The above equation can be also written in terms of design parameters as shown in the equation below:

$$
\begin{gathered}
\dot{\eta}=1.901 \times n_{2}-0.048 \times h l-12.891 \times p-0.016 \\
\times q+101.1
\end{gathered}
$$

\section{Conclusions}

The recycled crushed plastic was tested in this study as a filter media. To evaluate the performance of this material, the following conclusions are obtained:

(1) Set No. 1

The sand filter has better turbidity removal efficiency than that of plastic filters at the beginning of operation time. While the performance of plastic filters increases with the increasing of running time 
until it achieves removal efficiency equal or superior to that of sand filter. The removal efficiency range of sand and plastic filters (No. 2, No. 3 and No. 4) are 87\%-71\%, 91\%-74\%, 86\%-74\% and 87\%-73.8\%, respectively.

It was concluded that the curves of turbidity removal efficiency become close to each other when the flow rate is increased.

The fine plastic (filter No. 2) has better turbidity removal efficiency than other plastic filters (filter No. 3 and No. 4) and it has the same running time and head loss development.

The rate of head loss development (pressure drop across the filter) was slow in plastic filters than that of sand filters under different operation conditions, and can reach $21 \%-78 \%$. This behaviour leads to long filtration runs reached 20\%-30\% and more production in treated water;

\section{(2) Set No. 2}

The sand filter has better removal efficiency than dual filters when the filtration rates were 7.5, 10, 12.5 $\mathrm{m} / \mathrm{h}$ while the dual and sand filters have the same turbidity removal efficiency for filtration rate of $5 \mathrm{~m} / \mathrm{h}$. The increasing of sand to plastic ratio leads to the increase of turbidity removal efficiency. The removal efficiency of sand and plastic filters (filters No. 2, No. 3 and No. 4) are $86.7 \%-70 \%, 86.3 \%-71 \%$, $82.6 \%-71 \%$ and $85 \%-69.7 \%$, respectively.

The dual media filters are slower in head loss development due to the sand media filter under the same flow conditions. This leading to long filtration runs reach $12 \%-33 \%$ and more production in treated water.

Future study is important to use plastic media as a direct filtration process as compared with traditional media of direct filtration.

\section{References}

[1] J.L. Tuepker, C.A. Buescher, Operation and maintenance of rapid sand and mixed-media filters in a lime softening plant, Journal AWWA (American Water Works Association) 94 (6) (1968) 1377-1388.

[2] E.W. Steel, T.J. McGhee, Water Supply and Sewerage, 5th ed., McGraw-Hill International Book Company, Japan, 1984.

[3] S.R. Qasim, E.M. Motley, G. Zhu, Water Works Engineering, Planning, Design and Operation, Prentice Hall, Upper Saddle River, University of Michigan, USA, 2000.

[4] F.F. Eunpu, High rate filtration in Fairfax County Virginia, Journal American Water Works Association 60 (6) (1970) 340-348.

[5] G.P. Westerhoff, Experience with high filtration rates, J. AWWA 63 (6) (1971) 321-392.

[6] S.M. Al-Rawi, Turbidity removal of drinking water by dual media filtration, M.Sc. Thesis, University of Mosul, Mosul, Iraq, 1987.

[7] O.I. Mohammed, A comparison between the performance of the conventional and the dual media filters, M.Sc. Thesis, University of Basrah, Basrah, Iraq, 1989.

[8] T.L. Yohe, T.M. Getting, The Effect of Low Uniformity Coefficient Anthracite on Dual Media Filtration, The F.B. Leopold Company Inc., Pennsylvania, 1993, pp. 160-163.

[9] R.H. Al-Anbari, Selected alternatives for upgrading existing water treatment plants: A quantitative and qualitative improvement, Ph.D. Thesis, University of Technology, Baghdad, Iraq, 1997.

[10] H.A. Al-Ansary, Purification of water by using porcelanite as a local material, M.Sc. Thesis, University of Technology, Baghdad, Iraq, 1998.

[11] Q.A. Al-Najjar, The study of ability of local ninivite rocks in purification of drinking water, Master's Thesis, Faculty of Engineering, University of Baghdad, Iraq, 2000. (in Arabic).

[12] M.F. Al-Auraji, The capability of increasing the capacity of Al-Dora water treatment plant, M.Sc. Thesis, University of Technology, Baghdad, Iraq, 2003. 